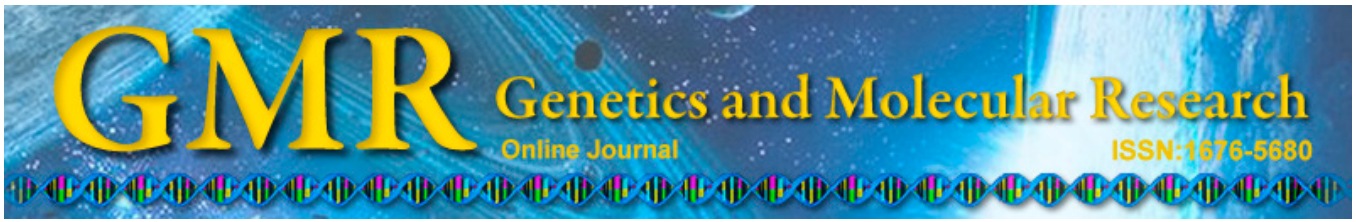

\title{
Association of PS1 1/2, ACE I/D, and LRP C/T polymorphisms with Alzheimer's disease in the Chinese population: a meta-analysis of case-control studies
}

\author{
L. Yang ${ }^{1 *}$, H.-H. Zhou ${ }^{1 *}$, Y.-F. Ye ${ }^{1 *}$, X.-W. Fan ${ }^{2}$, Y.-J. Wang ${ }^{3}$ and Y. Meng ${ }^{1}$ \\ ${ }^{1}$ Radiation Center of East Hepatobiliary Hospital, \\ Second Military Medical University, Shanghai, China \\ ${ }^{2}$ Department of Hepatobiliary Disease II of East Hepatobiliary Hospital, \\ Second Military Medical University, Shanghai, China \\ ${ }^{3}$ Department of Oncology, Changhai Hospital, \\ Second Military Medical University, Shanghai, China \\ *These authors contributed equally to this study. \\ Corresponding authors: Y.-J. Wang / Y. Meng \\ E-mail: wangyj_nature@163.com / mengyan201312@163.com \\ Genet. Mol. Res. 14 (1): 1017-1024 (2015) \\ Received January 9, 2014 \\ Accepted October 29, 2014 \\ Published February 6, 2015 \\ DOI http://dx.doi.org/10.4238/2015.February.6.5
}

\begin{abstract}
The objective of this study was to assess the associations of presenilin 1 (PS1) 1/2, angiotensin I-converting enzyme (ACE) insertion/deletion (I/D), and low-density lipoprotein receptor-related protein (LRP) C/T polymorphisms with the risk of Alzheimer's disease (AD) in the Chinese population. PS1 1/2, ACE I/D, and LRP C/T, which are commonly investigated polymorphisms, were evaluated to obtain summary estimates regarding their associations with $\mathrm{AD}$. In total, the data from 24 studies (2611 patients with $\mathrm{AD}$ and 2822 control subjects from 23 provinces and special districts in China) that were obtained from the Chinese Biomedicine Database, China National Knowledge Infrastructure, PubMed, and Medline were included. Different models (i.e., dominant, recessive, etc.) of these polymorphisms were analyzed using the Cochrane
\end{abstract}


Review Manager. Statistically significant associations among patients with $\mathrm{AD}$ for the $1 / 1$ genotype of the PS1 $1 / 2$ polymorphism [odds ratio $(\mathrm{OR})=1.77,95 \%$ confidence interval $(\mathrm{CI})=1.03-3.04 ; \mathrm{P}=0.04]$ and the $\mathrm{I} / \mathrm{I}$ genotype of the ACE I/D polymorphism $(\mathrm{OR}=2.44,95 \% \mathrm{CI}=$ 1.78-3.35; $\mathrm{P}<0.01$ ) were identified. Statistically significant associations were also found for the PS1 1/2 polymorphism in both the dominant and recessive genetic models, whereas no association was found for the LRP $\mathrm{C} / \mathrm{T}$ polymorphism. All studies exhibited heterogeneity $(\mathrm{P}<0.05)$. This meta-analysis suggests that the $1 / 1$ genotype of the PS1 $1 / 2$ polymorphism and the I/I genotype of the ACE I/D polymorphism are significantly associated with an increased risk of $\mathrm{AD}$ in the Chinese population.

Key words: Angiotensin-converting enzyme gene; Alzheimer's disease; Low-density lipoprotein receptor-related protein gene; Meta-analysis;

Presenilin 1 gene; Polymorphism

\section{INTRODUCTION}

Alzheimer's disease (AD) is a common cause of morbidity and mortality among the elderly. The brains of patients with AD are essentially characterized by neuronal and synaptic loss, extracellular plaques composed of amyloid- $\beta$ peptides, and intraneuronal neurofibrillary tangles consisting of hyperphosphorylated tau proteins. Genetic factors are believed to substantially contribute to an individual's risk of developing $\mathrm{AD}$, but the apolipoprotein E4 (APOE4) allele is the only genetic factor unequivocally associated with an increased risk of late-onset AD (LOAD) (Sorbi et al., 1997; Bi et al., 2000), and it has been estimated to account for less than half of all AD genetic risk factors.

Wragg et al. (1996) were the first to allude to an association of variations in the biallelic polymorphism of the presenilin 1 (PS1) gene with risk of AD. Subsequent research efforts on PS1 have yielded inconsistent results, with some studies (Wu et al., 2002; Pritchard et al., 2005) showing an association between PS1 allele 1 and AD risk, while others (Hu et al., 2000; McIlroy et al., 2001; Bian et al., 2005) demonstrating the opposite.

Kehoe et al. (1999) were among the first to indicate an association between AD and the insertion/deletion (I/D) polymorphism in intron 16 of the angiotensin I-converting enzyme (ACE) gene. This potential association has since been examined in more than 40 studies worldwide, with mixed results (Chen et al., 2004).

Low-density lipoprotein receptor-related protein (LRP) is a cell receptor for APOE and is involved in mediating APOE-dependent neurite growth and in the neuronal metabolism of secreted $\beta$-amyloid precursor proteins (Kounnas et al., 1995; Sánchez-Guerra et al., 2001). Kang et al. (1997) were the first to report that a polymorphism in exon 3 of LRP is a risk factor for AD. Likewise, subsequent studies on this LRP polymorphism have produced inconsistent results, with some studies finding positive associations with the C allele (Kang et al., 1997; $\mathrm{Wu}, 2002$ ) and others showing no association with $\mathrm{AD}$ (Wu et al., 1999; Zheng et al., 2004).

In China, genetic association studies are widely performed to evaluate the relationships between PS1, ACE, and LRP polymorphisms and AD risk. As with global population data sets, the obtained results for the Chinese population have been fairly inconsistent. In the present study, a meta-analysis of case-control studies assessing the associations between PS1 
1/2, ACE I/D, and LRP C/T polymorphisms, and the risk of AD in the Chinese population was performed to clarify the issues inherent in this subject matter.

\section{MATERIAL AND METHODS}

\section{Selection of studies}

A systematic computerized literature search of studies published before August 12, 2010 was conducted using the Chinese Biomedicine Database, China National Knowledge Infrastructure, PubMed, and Medline. "Alzheimer's disease", "PS1", "ACE", "LRP", "polymorphism", "China", and "Chinese" served as the search terms.

\section{Selection criteria}

Studies were considered eligible for this meta-analysis if they met the following criteria: 1) patients with $\mathrm{AD}$ fulfilled the DSM-III-R, DSM-IV, and NINCDS/ADRDA criteria; 2) overall risk estimates were available; and 3) distributions of genotypes followed the HardyWeinberg equilibrium (HWE).

\section{Data collection}

Two separate reviewers examined the retrieved data and extracted the following information: author, year of publication, sample size, distribution of genotypes and alleles in both $\mathrm{AD}$ and control groups, and characteristics of the study participants.

\section{Statistical analysis}

The strengths of the associations between the three gene polymorphisms and $\mathrm{AD}$ were evaluated using odds ratios (ORs) and the corresponding 95\% confidence intervals (CIs). Summary ORs based on the individual ORs were estimated using a random-effect model where there was heterogeneity between the studies; otherwise, a fixed-effect model was used. Statistical significance was determined using a $Z$-test. Funnel plots were used to investigate potential publication bias. All analytical procedures were performed using the Cochrane Review Manager (RevMan, version 5.0).

\section{RESULTS}

In total, 24 studies (12 for the PS1 gene, seven for the ACE gene, and five for the LRP gene), comprising 2611 patients with $\mathrm{AD}$ and 2822 control subjects from nine provinces and special districts in China, were included in this study.

The literature search identified 15 articles on the PS1 1/2 polymorphism, of which two duplicate publications and one review were excluded, leaving 12 articles for analysis (Table 1). The results of the meta-analysis on studies of the PS1 1/2 polymorphism are shown in Table 2.

According to the random-effect model, the summary ORs for $11 / 22,12 / 22,1 / 2$, the dominant model, and the recessive model were $1.77(95 \% \mathrm{CI}=1.03-3.04 ; \mathrm{P}=0.04), 1.45$ 
$(95 \% \mathrm{CI}=0.97-2.17 ; \mathrm{P}=0.07), 1.26(95 \% \mathrm{CI}=0.99-1.61 ; \mathrm{P}=0.06), 1.68(95 \% \mathrm{CI}=1.08-2.61$; $\mathrm{P}=0.02)$, and $0.68(95 \% \mathrm{CI}=0.58-0.79 ; \mathrm{P}<0.01)$, respectively.

\begin{tabular}{|c|c|c|c|c|c|c|c|c|c|}
\hline \multirow[t]{2}{*}{ Source } & \multirow[t]{2}{*}{ Area } & \multicolumn{4}{|c|}{ Sample age and gender } & \multicolumn{3}{|c|}{ Genotype frequency $[\mathrm{N}(\%)]$} & \multirow{2}{*}{$\begin{array}{c}\text { Frequency of } \\
1 \text { allele }(\%)\end{array}$} \\
\hline & & Group & Sample size & Age & Gender $(\mathrm{M} / \mathrm{F})$ & $1 / 1$ & $1 / 2$ & $2 / 2$ & \\
\hline \multirow[t]{2}{*}{ Tang et al. (1999) } & \multirow[t]{2}{*}{ Shanghai } & $\mathrm{AD}$ & 123 & $75.9 \pm 8.9$ & $59 / 64$ & $49(39.9)$ & $59(47.9)$ & $15(12.2)$ & 36.2 \\
\hline & & Control & 140 & $71.6 \pm 18.5$ & $60 / 80$ & $40(28.6)$ & $70(50.0)$ & $30(21.4)$ & 46.4 \\
\hline \multirow[t]{2}{*}{ Ma et al. (2000b) } & \multirow[t]{2}{*}{ Guangdong } & $\mathrm{AD}$ & 75 & $81 \pm 8$ & $29 / 46$ & $28(37.3)$ & $40(53.3)$ & $7(9.3)$ & 64.0 \\
\hline & & Control & 73 & $78 \pm 8$ & $39 / 34$ & $17(23.3)$ & $38(52.1)$ & $18(24.6)$ & 49.3 \\
\hline \multirow{2}{*}{ Chen et al. (2004) } & \multirow{2}{*}{ Guangdong } & $\mathrm{AD}$ & 66 & $67.9 \pm 6.4$ & $29 / 37$ & $25(37.9)$ & $35(53.0)$ & $6(9.1)$ & 64.4 \\
\hline & & Control & 143 & $68.3 \pm 6.0$ & $65 / 78$ & $33(23.1)$ & $75(52.4)$ & $35(24.4)$ & 49.3 \\
\hline \multirow[t]{2}{*}{ Wu (2002) } & \multirow{2}{*}{ Beijing } & $\mathrm{AD}$ & 135 & $73.63 \pm 8.62$ & $89 / 46$ & $54(40.0)$ & $57(42.2)$ & $24(17.8)$ & 61.1 \\
\hline & & Control & 138 & $69.64 \pm 5.43$ & $57 / 81$ & $63(45.7)$ & $65(47.1)$ & $10(7.2)$ & 69.2 \\
\hline \multirow[t]{2}{*}{ Wu et al. (1998) } & \multirow[t]{2}{*}{ Shanghai } & $\mathrm{AD}$ & 71 & $76.9 \pm 8.8$ & & $26(36.6)$ & $37(52.1)$ & $8(11.3)$ & 63.3 \\
\hline & & Control & 69 & $68.9 \pm 6.0$ & & $31(44.9)$ & $28(40.6)$ & $10(14.5)$ & 65.2 \\
\hline \multirow[t]{2}{*}{ Zhu et al. (2000) } & \multirow[t]{2}{*}{ Shandong } & $\mathrm{AD}$ & 32 & $73.1 \pm 6.5$ & & $11(34.4)$ & $17(53.1)$ & $4(12.5)$ & 39.1 \\
\hline & & Control & 32 & $72.8 \pm 6.85$ & & $12(37.5)$ & $18(56.3)$ & $2(6.3)$ & 34.3 \\
\hline \multirow[t]{2}{*}{ Ma et al. (2000a) } & \multirow[t]{2}{*}{ Guangdong } & $\mathrm{AD}$ & 103 & $83 \pm 12.6$ & $41 / 62$ & $38(36.9)$ & $47(45.6)$ & $18(17.5)$ & 59.7 \\
\hline & & Control & 98 & $80.6 \pm 9.5$ & $50 / 48$ & $19(19.4)$ & $57(58.2)$ & $22(22.4)$ & 48.5 \\
\hline \multirow[t]{2}{*}{ Bi et al. (1999) } & \multirow[t]{2}{*}{ Shandong } & $\mathrm{AD}$ & 43 & $73.2 \pm 6.8$ & & $18(41.9)$ & $22(51.2)$ & $3(6.9)$ & 65.1 \\
\hline & & Control & 46 & $73.4 \pm 7.5$ & & $23(50.0)$ & $20(43.5)$ & $3(6.5)$ & 68.5 \\
\hline \multirow[t]{2}{*}{ Zhang et al. (2004) } & \multirow[t]{2}{*}{ Jiangsu } & $\mathrm{AD}$ & 144 & $71.5 \pm 7.3$ & $72 / 72$ & $50(34.7)$ & $77(53.5)$ & $17(11.8)$ & 61.5 \\
\hline & & Control & 140 & $71.3 \pm 7.6$ & $71 / 69$ & $25(17.9)$ & $74(52.9)$ & $31(22.1)$ & 51.4 \\
\hline \multirow[t]{2}{*}{ Wu et al. (1999) } & \multirow[t]{2}{*}{ Shanghai } & $\mathrm{AD}$ & 91 & & & $39(42.9)$ & $44(48.4)$ & $8(8.8)$ & 67.0 \\
\hline & & Control & 73 & & & $29(39.7)$ & 34 (46.6) & $10(13.7)$ & 63.0 \\
\hline \multirow[t]{2}{*}{ Jia et al. (2006) } & \multirow[t]{2}{*}{ Hebei } & $\mathrm{AD}$ & 467 & $75.3 \pm 7.3$ & & $196(42.0)$ & $239(51.2)$ & $32(6.8)$ & 67.6 \\
\hline & & Control & 480 & & & $124(25.8)$ & $254(52.9)$ & $102(21.3)$ & 52.4 \\
\hline \multirow[t]{2}{*}{ Hu et al. (1998) } & \multirow[t]{2}{*}{ Taiwan } & $\mathrm{AD}$ & 55 & $78.2(62-69)$ & & $23(41.8)$ & $25(45.5)$ & $7(12.7)$ & 64.5 \\
\hline & & Control & 93 & $79.2(67-87)$ & & $42(45.2)$ & $41(44.1)$ & $10(10.7)$ & 67.2 \\
\hline
\end{tabular}

Table 2. Meta-analysis of association between PS1 polymorphism and AD risk.

\begin{tabular}{lcccrr}
\hline Gene polymorphism & $\mathrm{I}^{2}(\%)$ & Model & Pooled OR & OR (95\%CI) & \multicolumn{1}{c}{$Z$} \\
\hline $1 / 2$ & 75 & Random effects & 1.26 & $0.99-1.61$ & 1.86 \\
$11 / 22$ & 76 & Random effects & 1.77 & $1.03-3.04$ & 2.05 \\
$12 / 22$ & 60 & Random effects & 1.45 & $0.97-2.17$ & 0.06 \\
Recessive & 61 & Random effects & 0.68 & $0.58-0.79$ & 5.00 \\
Dominant & 70 & Random effects & 1.68 & $1.08-2.61$ & 2.31 \\
\hline
\end{tabular}

For the LRP C/T polymorphism, the literature search identified 12 articles, of which five met the selection criteria (Table 3). Among the seven excluded articles, two were duplicated publications, three did not follow the HWE model, and two did not report the distribution of genotypes. The results of the meta-analysis are shown in Table 4.

According to the random-effect model, the summary ORs for T/C, CT/CC, and the dominant model were $0.80(95 \% \mathrm{CI}=0.45-1.44 ; \mathrm{P}=0.46), 0.80(95 \% \mathrm{CI}=0.43-1.47 ; \mathrm{P}=$ $0.47)$, and $0.81(95 \% \mathrm{CI}=0.49-1.37 ; \mathrm{P}=0.44)$, respectively. In the fixed-effect model, the summary ORs for TT/CC and the recessive model were $0.59(95 \% \mathrm{CI}=0.19-1.85 ; \mathrm{P}=0.37)$ and $1.47(95 \% \mathrm{CI}=0.47-4.58 ; \mathrm{P}=0.51)$, respectively.

Thirteen articles were identified for the ACE I/D polymorphism, of which seven met the selection criteria (Table 5). Among the six excluded articles, three were duplicated publications and three did not follow the HWE model. The results of the meta-analysis are shown in Table 6. 
Table 3. Characteristics of studies included in the analyses and distribution of LRP genotypes and alleles for cases and controls.

\begin{tabular}{|c|c|c|c|c|c|c|c|c|c|}
\hline \multirow[t]{2}{*}{ Study } & \multirow[t]{2}{*}{ Area } & \multicolumn{4}{|c|}{ Sample age and gender } & \multicolumn{3}{|c|}{ Genotype frequency [N (\%)] } & \multirow{2}{*}{$\begin{array}{c}\text { Frequency of } \\
\text { C allele (\%) }\end{array}$} \\
\hline & & Group & Sample size & Age & Gender (M/F) & $\mathrm{C} / \mathrm{C}$ & $\mathrm{C} / \mathrm{T}$ & $\mathrm{T} / \mathrm{T}$ & \\
\hline \multirow[t]{2}{*}{ Chen et al. (2009) } & \multirow[t]{2}{*}{ Shanxi } & $\mathrm{AD}$ & 67 & $71.93 \pm 7.23$ & $44 / 23$ & $59(88.1)$ & $8(11.9)$ & $0(0.0)$ & 94.0 \\
\hline & & Control & 77 & $70.04 \pm 4.31$ & $42 / 35$ & $56(72.7)$ & $19(24.7)$ & $2(2.60)$ & 85.1 \\
\hline \multirow[t]{2}{*}{ Bi et al. (2000) } & \multirow[t]{2}{*}{ Heilongjiang } & $\mathrm{AD}$ & 42 & $60-79$ & $23 / 19$ & 33 (78.6) & 7 (16.7) & $2(4.7)$ & 86.9 \\
\hline & & Control & 40 & $60-81$ & $24 / 16$ & $23(57.5)$ & $13(32.5)$ & $4(10.0)$ & 73.8 \\
\hline \multirow[t]{2}{*}{ Zheng et al. (2004) } & \multirow[t]{2}{*}{ Guangxi } & $\mathrm{AD}$ & 79 & $72.8 \pm 9.5$ & $40 / 39$ & $72(91.1)$ & $6(7.6)$ & $1(1.3)$ & 94.9 \\
\hline & & Control & 156 & $71.2 \pm 9.3$ & $92 / 64$ & $139(89.1)$ & $16(10.3)$ & $1(0.6)$ & 94.2 \\
\hline \multirow[t]{2}{*}{ Hu et al. (2000) } & \multirow[t]{2}{*}{ Taiwan } & $\mathrm{AD}$ & 82 & $78.2(62-69)$ & & $66(80.5)$ & $16(19.5)$ & $0(0.0)$ & 90.2 \\
\hline & & Control & 110 & $79.2(67-87)$ & & $98(89.1)$ & $12(10.9)$ & $0(0.0)$ & 94.5 \\
\hline \multirow[t]{2}{*}{ Bian et al. (2005) } & \multirow[t]{2}{*}{ Shanghai } & $\mathrm{AD}$ & 216 & & & $189(87.5)$ & $26(12.0)$ & $1(0.5)$ & 93.5 \\
\hline & & Control & 200 & & & $179(89.5)$ & $21(10.5)$ & $0(0.0)$ & 94.8 \\
\hline
\end{tabular}

Table 4. Meta-analysis of association between the LRP gene polymorphism and AD risk.

\begin{tabular}{lclccc}
\hline Gene polymorphism & $\mathrm{I}^{2}(\%)$ & Model & Pooled OR & OR $(95 \% \mathrm{CI})$ & $Z$ \\
\hline T/C & 66 & Random effects & 0.80 & $0.45-1.44$ & 0.74 \\
TT/CC & 0 & Fixed effects & 0.59 & $0.19-1.85$ & 0.46 \\
CT/CC & 62 & Random effects & 0.80 & $0.43-1.47$ & 0.73 \\
Dominant & 58 & Random effects & 0.81 & $0.49-1.37$ & 0.77 \\
Recessive & 0 & Fixed effects & 1.47 & $0.47-4.58$ & 0.66 \\
\hline
\end{tabular}

\begin{tabular}{|c|c|c|c|c|c|c|c|c|c|}
\hline \multirow[t]{2}{*}{ Study } & \multirow[t]{2}{*}{ Area } & \multicolumn{4}{|c|}{ Sample age and gender } & \multicolumn{3}{|c|}{ Genotype frequency $[\mathrm{N}(\%)]$} & \multirow{2}{*}{$\begin{array}{l}\text { Frequency of } \\
\text { D allele }(\%)\end{array}$} \\
\hline & & Group & Sample size & Age & Gender $(\mathrm{M} / \mathrm{F})$ & $\mathrm{D} / \mathrm{D}$ & $\mathrm{I} / \mathrm{D}$ & $\mathrm{I} / \mathrm{I}$ & \\
\hline \multirow[t]{2}{*}{ Liu et al. (2007) } & \multirow[t]{2}{*}{ Jiangsu } & $\mathrm{AD}$ & 39 & $70.2 \pm 7.8$ & $15 / 24$ & $5(12.8)$ & $12(30.8)$ & $22(56.4)$ & 28.2 \\
\hline & & Control & 50 & $72.1 \pm 7.3$ & $26 / 24$ & $11(22.0)$ & $21(42.0)$ & $18(36.0)$ & 43.0 \\
\hline \multirow[t]{2}{*}{ Wu et al. (2002) } & \multirow[t]{2}{*}{ Beijing } & $\mathrm{AD}$ & 96 & $71.5 \pm 6.1$ & $33 / 63$ & $12(12.5)$ & $44(45.8)$ & $40(41.7)$ & 35.4 \\
\hline & & Control & 96 & $70.1 \pm 5.4$ & $33 / 63$ & $25(26.0)$ & $47(49.0)$ & $24(25.0)$ & 50.5 \\
\hline \multirow{2}{*}{ Han and Zhang (2008) } & \multirow[t]{2}{*}{ Shanxi } & $\mathrm{AD}$ & 55 & $75.5 \pm 9.3$ & $34 / 21$ & $12(21.8)$ & $19(34.6)$ & $24(43.6)$ & 39.1 \\
\hline & & Control & 59 & $72.3 \pm 8.0$ & $35 / 24$ & $10(17.0)$ & $32(54.2)$ & $17(28.8)$ & 44.1 \\
\hline \multirow[t]{2}{*}{ Wang et al. (2006) } & \multirow[t]{2}{*}{ Taiwan } & $\mathrm{AD}$ & 151 & $74.8 \pm 7.9$ & $62 / 89$ & $27(17.9)$ & $59(39.1)$ & $65(43.0)$ & 37.4 \\
\hline & & Control & 161 & $62.5 \pm 8.7$ & $85 / 76$ & $9(5.6)$ & $59(36.6)$ & $93(57.8)$ & 34.7 \\
\hline \multirow[t]{2}{*}{ Ning et al. (2010) } & \multirow[t]{2}{*}{ Shanghai } & $\mathrm{AD}$ & 138 & & & $17(12.3)$ & $39(28.3)$ & $82(59.4)$ & 26.4 \\
\hline & & Control & 469 & & & $67(14.3)$ & $229(48.8)$ & $173(36.9)$ & 36.9 \\
\hline \multirow[t]{2}{*}{ Li (2003) } & \multirow[t]{2}{*}{ Guangxi } & $\mathrm{AD}$ & 68 & & $26 / 42$ & $7(10.3)$ & $21(30.9)$ & $40(58.8)$ & 25.7 \\
\hline & & Control & 156 & & $105 / 52$ & $19(12.1)$ & $77(49.4)$ & $60(38.5)$ & 36.9 \\
\hline \multirow[t]{2}{*}{ Cheng et al. (2002) } & \multirow[t]{2}{*}{ Taiwan } & $\mathrm{AD}$ & 173 & $74.4 \pm 6.4$ & $97 / 76$ & $9(5.2)$ & $79(45.7)$ & $85(49.1)$ & 28.0 \\
\hline & & Control & 286 & & $145 / 141$ & $39(13.6)$ & $126(44.1)$ & $121(42.3)$ & 37.7 \\
\hline
\end{tabular}

Table 6. Meta-analysis of association between the ACE I/D polymorphism and AD risk.

\begin{tabular}{lllcrr}
\hline Gene polymorphism & $\mathrm{I}^{2}(\%)$ & Model & Pooled OR & OR $(95 \% \mathrm{CI})$ & \multicolumn{1}{c}{ P } \\
\hline I/D & 89 & Random effects & 1.41 & $0.88-2.26$ & 1.42 \\
II/DD & 0 & Fixed effects & 2.44 & $1.78-3.35$ & 5.54 \\
ID/DD & 69 & Random effects & 0.95 & $0.70-1.28$ & 0.35 \\
Dominant & 71.59 & Random effects & 0.62 & $0.31-1.22$ & 1.38 \\
Recessive & 78 & Random effects & 1.28 & $0.66-2.50$ & 0.72 \\
\hline
\end{tabular}


The summary OR for II/DD was $2.44(95 \% \mathrm{CI}=1.78-3.35 ; \mathrm{P}<0.01)$ in the fixedeffect model. According to the random-effect model, the summary ORs for ID/DD, I/D, the dominant model, and the recessive model were $0.95(95 \% \mathrm{CI}=0.70-1.28 ; \mathrm{P}=0.72), 1.41$ $(95 \% \mathrm{CI}=0.88-2.26 ; \mathrm{P}=0.16), 0.62(95 \% \mathrm{CI}=0.31-1.22 ; \mathrm{P}=0.17)$, and $1.28(95 \% \mathrm{CI}=0.66-$ $2.50 ; \mathrm{P}=0.46)$, respectively.

\section{DISCUSSION}

The present study differs from previous meta-analyses in that it focused on the Chinese population. The most extensive studies on the three polymorphisms, including recently published articles and all related articles published in English and Chinese, were included.

One meta-analysis disclosed a significant association between the PS1 1/1 genotype and LOAD in both Caucasian and Japanese populations (Pritchard et al., 2005). Another metaanalysis found that the PS1 2/2 genotype is a risk factor for LOAD in the Spanish population (Chen et al., 2009). Owing to language restrictions, only two studies in the Chinese population were included in that meta-analysis. Hence, the specific objective of the present meta-analysis was to examine whether PS1 is associated with AD in the Chinese population.

The positive association of the PS1 polymorphism with AD may be attributed to the polymorphism itself as well as the disequilibrium between this locus and another active locus in the PS1 gene. This study attempted to further investigate possible interactions between the APOE and PS1 genes, but the limited number of eligible studies made this impractical.

LRP is known to facilitate the delivery of cell surface amyloid precursor proteins to indusial compartments. Sánchez-Guerra et al. (2001) conducted a meta-analysis of eight studies and found a weak correlation between the LRP CC genotype and AD. Pritchard et al. (2005) performed a meta-analysis on the data of 4668 patients with $\mathrm{AD}$ and 4473 control subjects but found no evidence for the involvement of the LRP C/T polymorphism in either increasing the susceptibility to $\mathrm{AD}$, or acting as a phenotypic modifier. However, only two studies on the Chinese population were included in their meta-analysis. To examine whether the LRP C/T polymorphism is associated with $\mathrm{AD}$ in the Chinese population, the present study included five studies involving 484 patients and 583 control subjects; however, no association between the LRP C/T polymorphism and AD risk was observed. Previous research on the relationship between LRP gene polymorphisms and $\mathrm{AD}$ risk has used a smaller number of publications and samples, and the positive findings might have been obtained by chance.

The association between the ACE I/D polymorphism and AD was similar across different ethnic groups. Elkins et al. (2004) found that the I allele of the ACE I/D polymorphism is associated with an increased risk of LOAD. In addition, their studies involving Asian subjects demonstrated a more robust and consistent association between the I allele and AD than those involving Caucasian subjects. In another meta-analysis (Chen et al., 2004), three ethnic groups (North European, South Caucasian, and East Asian subjects) were examined, and the results confirmed the association between $\mathrm{ACE} \mathrm{I} / \mathrm{D}$ and $\mathrm{AD}$ across diverse populations. Both meta-analyses suggested that the I allele increased the risk of AD. Only two studies conducted on the Chinese population were available, one of which did not follow the HWE model (Sánchez-Guerra et al., 2001), and, therefore, no conclusions could be drawn for the association between ACE polymorphisms and AD risk.

The association between ACE polymorphisms and AD suggests that the ACE I/D polymorphism is closely linked to the disequilibrium of another truly causal polymorphism 
in ACE. Indeed, rs4291 and rs4343 have been reported to be linked to the disequilibrium in the I/D polymorphism (Saunders et al., 1993); moreover, rs4291 polymorphisms have shown significant summary ORs in the AlzGene (Bertram and Tanzi, 2004). Previous research has also confirmed that the rs4343 A allele is associated with the risk of LOAD in the Chinese population (Hollenbach et al., 1998).

Several limitations should be considered in interpreting our results. First, owing to data limitations, the studies could not be divided into subgroups by age. Second, owing to the lack of original data, an evaluation of potential interactions (e.g., gene-gene and genetic-environment) was not performed, which may have influenced the results. Third, publication bias might have occurred when the effect of PS1 1/2 on AD risk was investigated. This study did not investigate any possible publication bias for the data on LRP and ACE, as fewer than nine articles were identified. Furthermore, with only published studies considered for the metaanalysis, publication bias might have affected the findings.

\section{CONCLUSIONS}

The PS1 1/2 genotype and the ACE I/D genotype are significantly associated with an increased risk of $\mathrm{AD}$ in the Chinese population. Further large-scale studies are necessary to confirm our findings and inform a better understanding of the associations between PS1 1/2, ACE I/D, and LRP C/T polymorphisms, and AD.

\section{Conflicts of interest}

The authors declare no conflict of interest.

\section{REFERENCES}

Bertram L and Tanzi RE (2004). Alzheimer's disease: one disorder, too many genes? Hum. Mol. Genet. 13 (Spec. No. 1): R135-141.

Bi JH, Zhang JH and Wang YJ (1999). Association between presinilin 1 gene and Alzheimer's disease. Qianwei Med. J. 16: 37-39.

Bi S, Wang DS and Zhang Y (2000). Two polymorphisms in the LRP gene and Alzheimer's disease. Chin. J. Neurol. 31: 10-13.

Bian L, Yang JD, Guo TW, Duan Y, et al. (2005). Association study of the A2M and LRP1 genes with Alzheimer disease in the Han Chinese. Biol. Psychiatry 58: 731-737.

Chen HD, Liu XH and Wang YP (2004). Association analysis between polymorphism of presinilin 1 gene and Alzheimer's disease. J. Mod. Clin. Med. Eng. 10: 220-223.

Chen Y, Zhang SL and Yue Y (2009). Relationship between the polymorphism of low density lipoprotein receptor 3 related protein gene, butyrylcholinesterase 2K variant and Alzheimer's disease. Pract Geriatr. 23: 132-135.

Cheng CY, Hong CJ, Liu HC, Liu TY, et al. (2002). Study of the association between Alzheimer's disease and angiotensinconverting enzyme gene polymorphism using DNA from lymphocytes. Eur. Neurol. 47: 26-29.

Elkins JS, Douglas VC and Johnston SC (2004). Alzheimer disease risk and genetic variation in ACE: a meta-analysis. Neurology 62: 363-368.

Han B and Zhang SL (2008). Association of apoE gene A2M gene and ACE gene polymorphism with Alzheimer's disease. Shanxi Med. Univ. 39: 692-710.

Hollenbach E, Ackermann S, Hyman BT and Rebeck GW (1998). Confirmation of an association between a polymorphism in exon 3 of the low-density lipoprotein receptor-related protein gene and Alzheimer's disease. Neurology 50: 19051907.

Hu CJ, Sung SM, Liu HC and Chang JG (1998). Association of apolipoprotein E genotype and intronic polymorphism of the presenilin-1 gene with Alzheimer's disease in elderly Taiwan Chinese. J. Neurol. Sci. 157: 158-161. 
Hu CJ, Sung SM, Liu HC, Hsu WC, et al. (2000). Genetic risk factors of sporadic Alzheimer's disease among Chinese in Taiwan. J. Neurol. Sci. 181: 127-131.

Jia L, Zhou C, Lv H, Wang W, et al. (2006). Association between presenilin 1 intronic polymorphism and late onset Alzheimer's disease in the North Chinese population. Brain Res. 1116: 201-205.

Li S (2003). Study on Gene Related with Late-Onset Alzheimer Disease. Tianjin Normal University, Tianjin.

Liu M, Zhang YD and Zhao KR (2007). Association of angiotensin converting enzyme activity and angiogenesis converting enzyme gene polymorphism. Chin. J. Pract. Med. 27: 1028-1031.

Kang DE, Saitoh T, Chen X, Xia Y, et al. (1997). Genetic association of the low-density lipoprotein receptor-related protein gene (LRP), an apolipoprotein E receptor, with late-onset Alzheimer's disease. Neurology 49: 56-61.

Kehoe PG, Russ C, McIlory S, Williams H, et al. (1999). Variation in DCP1, encoding ACE, is associated with susceptibility to Alzheimer disease. Nat. Genet. 21: 71-72.

Kounnas MZ, Moir RD, Rebeck GW, Bush AI, et al. (1995). LDL receptor-related protein, a multifunctional ApoE receptor, binds secreted beta-amyloid precursor protein and mediates its degradation. Cell 82: 331-340.

Ma C, Li Q and Feng RM (2000a). Genetic association among polymorphism in presenilin 1 gene, ApoE gene and late onset Alzheimer's disease. Chin. J. Nerv. Ment. Dis. 26: 345-348.

Ma QL, Qian CY and Liu ZL (2000b). Intronic polymorphism of presenlin-1 gene with Alzheimer disease. Chin. J. Neurol. 33: 283-285.

Ning M, Yang Y, Zhang Z, Chen Z, et al. (2010). Amyloid- $\beta$-related genes SORL1 and ACE are genetically associated with risk for late-onset Alzheimer disease in the Chinese population. Alzheimer Dis. Assoc. Disord. 24: 390-396.

McIlroy SP, Dynan KB, Vahidassr DJ, Lawson JT, et al. (2001). Common polymorphisms in LRP and A2M do not affect genetic risk for Alzheimer disease in Northern Ireland. Am. J. Med. Genet. 105: 502-506.

Pritchard A, Harris J, Pritchard CW, St Clair D, et al. (2005). Association study and meta-analysis of low-density lipoprotein receptor related protein in Alzheimer's disease. Neurosci. Lett. 382: 221-226.

Sánchez-Guerra M, Combarros O, Infante J, Llorca J, et al. (2001). Case-control study and meta-analysis of low density lipoprotein receptor-related protein gene exon 3 polymorphism in Alzheimer's disease. Neurosci. Lett. 316: 17-20.

Saunders AM, Strittmatter WJ, Schmechel D, George-Hyslop PH, et al. (1993). Association of apolipoprotein E allele epsilon 4 with late-onset familial and sporadic Alzheimer's disease. Neurology 43: 1467-1472.

Sorbi S, Nacmias B, Tedde A, Forleo P, et al. (1997). Presenilin-1 gene intronic polymorphism in sporadic and familial Alzheimer's disease. Neurosci. Lett. 222: 132-134.

Tang GM, Zhang MY and Jiang SD (1999). Association analysis between antichymotrypsin gene, presinilin 1 gene and Alzheimer's disease in China. Chin. J. Nerv. Ment. Dis. 25: 31-33.

Wang HK, Fung HC, Hsu WC, Wu YR, et al. (2006). Apolipoprotein E, angiotensin-converting enzyme and kallikrein gene polymorphisms and the risk of Alzheimer's disease and vascular dementia. J. Neural. Transm. 113: 1499-1509.

Wragg M, Hutton M and Talbot C (1996). Genetic association between intronic polymorphism in presenilin-1 gene and late-onset Alzheimer's disease. Alzheimer's Disease Collaborative Group. Lancet 347: 509-512.

Wu C, Zhou D, Guan Z, Fan J, et al. (2002). The association between angiotensin I converting enzyme gene polymorphism and Chinese late onset Alzheimer disease. Zhonghua Yi Xue Yi Chuan Xue Za Zhi 19: 401-404.

Wu DB (2002). Analysis of Presenlin-1, Apoe and MTHFR Polymorphism or Mutations in Patients with Dementia [D]. The General Hospital of Chinese Peoples Liberation Army, Beijing.

Wu X, Jiang S, Lin S, Tang G, et al. (1999). No association between the intronic presenilin 1 polymorphism and Alzheimer's disease in the Chinese population. Am. J. Med. Genet. 88 1-3.

Wu XD, Jiang SD and Jin TG (1998). Association analysis of presenilin 1 polymorphism with Alzheimer's disease. Chin. J. Geriatr. 17: 143-145.

Wu XD, Jiang SD and Lin SC (2000). No association between the intronic presenilin 1 polymorphism and Alzheimer's disease in the Chinese Population. Am. J. Med. Genet. 88: 1-3.

Zhang YD, Shen W and Ke XY (2004). Correlation between intronic polymorphism of presinilin 1 gene and sporadic Alzheimer's disease. Chin. J. Rehabil. 8: 6876-6878.

Zheng WD, Zheng HJ and Yang Z (2004). A Genetic Association Study between the Cardiovascular Risk Factor and lateonset Alzheimer Disease in Guangxi Han Chinese. Chin. J. Neuroimmunol. Neuron 11: 68-70.

Zhu JY, Xu WL and Gao Y (2000). Intronic polymorphism of presinilin 1 gene with Alzheimer's disease. Shandong Med. J. 40: $14-17$. 